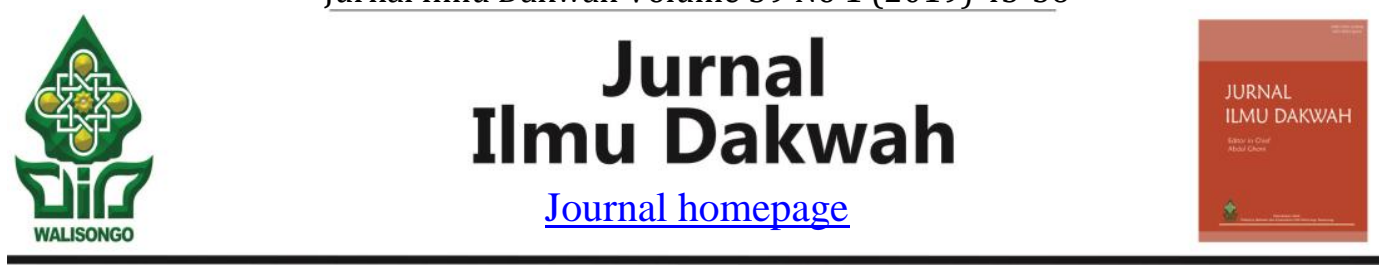

\title{
Peranan Dakwah Mr. Sjafruddin Prawiranegara dalam Menyelamatkan Republik
}

\author{
Sriyanto ${ }^{1)}$ \\ ${ }^{1}$ Sistem Informasi, Fakultas Ilmu Komputer Universitas Amikom Purwokerto \\ email: sriyantooop@gmail.com
}

\begin{abstract}
Mr. Sjafruddin Prawiranegara is a unique figure in thinking and preaching. He was a great preacher and given contributions for republic. Another learning, da'i should not be prosecutor and judge. Sjafruddin role, as a da'i the president often erased from history books. Based on this, Study entitled the role Sjafruddin Prawiranegara Dakwah in saving Republic was carried out. This research very important because to re-read role of Mr. Sjafruddin Dakwah, da'i warrior who has saved existence and sustainability of Republic as part of his faith. This research is limited to role of his dakwah, biography, concept of struggle and relevance his dakwah. This research is qualitative as a library with interpretative approach. The results of research indicate that his dakwah based on strong Islamic worldview. Digest Dakwah covering faith and reason is basis of preaching. "Greater reason dangerous for Islam than opponents openly hostile" Sjafruddin said. The main role Sjafruddin dakwah was his courage and firmness to save Indonesia from destruction defeat when the second military aggression. The role of his dakwah includes all fields. His View thinks far ahead, so many still and remain relevant. He said that "preaching is inseparable from state and political matters"
\end{abstract}

Keywords: Integral, Sjafruddin, Da'wah

Mr. Sjafruddin Prawiranegara adalah tokoh yang unik dalam dakwahnya. Dia adalah teladan dan sudah memberi sumbangsihnya bagi Republik. Pembelajaran unik dari Sjafruddin yaitu; seorang da'i seharusnya tidak menjadi jaksa dan hakim. Peranan Sjafruddin sebagai dai yang presiden sering terhapus dari buku sejarah Indonesia. Berdasarkan hal tersebut maka penelitian berjudul Peranan Dakwah Mr. Sjafruddin Prawiranegara dalam menyelamatkan Republik dilaksanakan. Penelitian ini sangat penting dilakukan karena membaca kembali peranan dakwah Mr. Sjafruddin, seorang da'i pejuang yang telah menyelamatkan keberadaan dan keberlangsungan Republik sebagai bagian imannya. Penelitian ini dibatasi pada peranan dakwahnya, biografi, konsep dan relevansi dakwahnya. Penelitian ini merupakan penelitian kualitatif. Penelitian bersifat 
penelitian pustaka dengan pendekatan interpretasi. Hasil penelitian menunjukkan bahwa seluruh aktivitas dakwahnya didasari Islamic worldview yang kuat. Iman dan akal merupakan dasar berdakwah. "Bahaya akal lebih besar bagi Islam dari lawan yang secara terang-terangan memusuhi Islam" kata Sjafruddin; Peran utama dakwah Sjafruddin adalah keberanian dan ketegasannya dalam mengambil tindakan untuk mengambil alih menyelamatkan Indonesia dari kehancuran dan kekalahan ketika terjadi agresi militer Belanda ke-2. Peranan dakwahnya mencakup semua bidang. Pandangannya jauh ke depan, sehingga banyak pemikirannya yang masih dan tetap relevan di masa sekarang. Dia pernah berkata bahwa "berdakwah itu tidak bisa dilepaskan dari soal kenegaraan dan politik".

Kata kunci: Integral, Sjafruddin, Dakwah

\section{Pendahuluan}

Mr. Sjafruddin Prawiranegara adalah tokoh yang unik dalam dakwahnya. Dia dilahirkan di Anyar Kidul, Kabupaten Serang, Propinsi Banten, pada tanggal 28 Februari 1911. Wakil Presiden Boediono mengatakan bahwa: Mr Sjafruddin adalah teladan dan sudah memberi sumbangsihnya bagi bangsa dan negara. "Beliau merupakan putra terbaik bangsa dan telah memberikan sumbangsih besar untuk bangsa Indonesia dan yang paling penting adalah beliau merupakan pribadi yang menjadi suri teladan dengan nilai luhur bagi pemimpin bangsa ini," kata wapres saat memberi sambutan pada acara peringatan seabad Mr. Sjafruddin. Pembelajaran unik lainnya dari Sjafruddin ialah mengenai ketegasannya ketika aktif menjadi ketua Korps Mubaligh Indonesia. Sjafruddin menyarankan kepada para da'i dengan mengatakan: "Kita harus cukup tegas memahamkan supaya tidak menimbulkan kesalah pemahaman", agar yang dihimbau mau mendengar dan mengikutinya ${ }^{1}$. Selanjut nya dia berkata; seorang da'i seharusnya tidak menjadi jaksa dan hakim.

Tidak bisa dilupakan jasa Sjafruddin dalam mempertahankan kedaulatan NKRI sangatlah besar. Penentu kebijakan sejarah telah membelokkan beberapa fakta termasuk mendistorsi peran Sjafruddin dalam sejarah bangsa dari seorang da'i yang pejuang. Ketika terjadi agresi militer Belanda II menjadi penyelamat republik dengan berinisiatif membentuk Pemerintah Darurat Republik Indonesia (PDRI). Demikian pula semasa Pemerintah Revolusioner Republik Indonesia (PRRI) dan Sjafruddin menjadi perdana menteri dalam kabinetnya. Ada yang menganggap PRRI sebagai pemberontakan berbahaya yang ingin merebut kedaulatan bangsa Indonesia, meskipun sebagian pihak menganggap bahwa kenyataan sebenarnya tidak demikian. Padahal PRRI muncul karena efek dari akan terjadinya disintegrasi dan adanya ketidakadilan pemerintah pusat saat itu. Pada waktu itu telah terjadi kesenjangan antara pemerintah pusat dan daerah. Pemerintah cenderung mengutamakan kepentingan pemerintah pusat serta ditambah terdapat campur tangan komunis yang terlalu berpengaruh. Kini disadari PRRI melakukan revolusi karena memang situasi saat itu memaksa untuk melakukan tindakan tersebut. Mereka melakukan itu karena ingin mengoreksi dan meluruskan keadaan. Jikalau zaman sekarang PRRI mungkin hampir mirip dengan reformasi. Pemerintah sendiri, khususnya Kementerian Pertahanan (Kemenhan) seharusnya juga menilai persoalan PRRI menjadi lebih clear dengan pemberian penghargaan pahlawan kepada Mr. Sjafruddin Prawiranegara.

Pemikiran dan dakwah Mr. Sjafruddin Prawiranegara selalu berpangkaltolak pada kemutlakan iman yang bulat. Kemutlakan imanlah yang menjadi pangkal tolak dalam menyelamatkan republik ini dari jajahan Belanda, dari kesewenang-wenangan dan ketidakadilan. Mr. Sjafruddin sangat tegas dan istiqamah dalam beramar ma'ruf nahi

${ }^{1}$ Brosur Pedoman untuk menjalankan Dakwah Islamiyah Indonesia , Yayasan Korps Muballigh Indonesia, Jakarta.1985 
munkar. Kritik-kritik tajam dan solusinya senantiasa disuarakannya dengan lantang, apalagi ketika melihat ketimpangan-ketimpangan sosial terjadi dimana-mana. Para pemimpinpun tidak lepas diingatkan sehingga kadang sering dipermasalahkan sampaisampai dipenjarakan. Mr. Sjafruddin berprinsip bahwa mengingatkan dengan ikhlas adalah sesuatu yang amat mulia. Semua aktivitas hidupnya senantiasa diarahkan untuk menggapai dan mengharap karunia dan ridha Allah Subhanahu Wata'ala. Peranan Sjafruddin sebagai dai yang presiden sering terhapus dari buku sejarah Indonesia. Hilangnya nama Sjafruddin disebabkan peran sertanya dalam Pemerintahan Revolusioner Republik Indonesia di masa Soekarno, serta suara kritisnya menentang kebijakan Soeharto².

Pakar ilmu politik dari Universitas Indonesia, Prof. Dr. Salim Said mengatakan bahwa, berbicara tentang Sjafruddin Prawiranegara, tidak bisa tidak bicara tentang dua hal: PDRI dan PRRI (Pemerintah Revolusioner Republik Indonesia). PDRI membuktikan dengan jelas jasa Sjafruddin menyelamatkan Republik Indonesia yang pemimpinnya sudah ditawan oleh Belanda. Sedangkan PRRI haruslah dilihat sebagai usaha menyelamatkan RI yang terancam oleh komunisme.

Berdasarkan hal tersebut maka penelitian berjudul Peranan Dakwah Mr. Sjafruddin Prawiranegara dilaksanakan. Penelitian ini sangat penting dilakukan karena memulai membaca kembali peranan dakwah Mr. Sjafruddin, seorang da'i pejuang yang telah menyelamatkan keberadaan dan keberlangsungan Republik Indonesia sebagai bagian dari imannya. Penelitian ini dibatasi pada biografi, intisari dakwahnya dan perjanan, relevansi dakwah Mr. Sjafruddin Prawiranegara.

Berdasarkan latar belakang dan rumusan masalah, maka tujuan yang ingin dicapai dari penelitian yang dilakukan adalah untuk: 1) mengetahui intisari dakwah Mr. Sjafruddin Prawiranegara; 2) mengetahui peranan dakwah Mr. Sjafruddin Prawiranegara; 3)mengetahui relevansi dakwah Mr. Sjafruddin Prawiranegara di masa sekarang dan akan datang.

\section{Biografi Singkat Mr. Sjafruddin Prawiranegara}

Sjafruddin Prawiranegara dilahirkan di Anyar Kidul, Kabupaten Serang, Propinsi Banten, pada tanggal 28 Februari 1911, sebagai anak kedua dari Raden Arsjad Prawiraatmadja. Dia datang dari keluarga priyayi Banten yang taat beragama. Sjafruddin Prawiranegara keturunan campuran Banten dan Minang. Darah yang mengalir dalam tubuhnya merupakan campuran Banten dan Minang. Buyut Sjafruddin, yang bernama Sutan Alam Intan masih merupakan keturunan Raja Pagaruyung di Sumatra Barat. Sutan Alam pernah dibuang ke Banten karena terlibat Perang Padri, akhirnya Sutan Alam menikah dengan putri seorang bangsawan dari Banten. Cucu Sutan Alam ini bernama Raden Arsjad Prawiraatmadja, inilah ayah Sjafruddin yang pernah bekerja sebagai jaksa. ${ }^{3}$ Jadi bapak kandung Mr. Sjafruddin Prawiranegara adalah Raden Arsjad Prawiraadmadja. Raden Arsjad sangat dikenal cukup dekat dengan rakyat. Raden Arjad juga pernah aktif dalam Sarekat Islam cabang Kabupaten Serang. Kedekatannya dengan rakyat inilah yang menyebabkan Arsjad dipindah tugaskan ke Kabupaten Ngawi sebagai pemindahan hukuman (strafoverplaatsing).

Pengaruh menak/kebangsawanan pada diri Sjafruddin masih agak terlihat sekali, ayahnya juga terkadang masih suka mengikuti kebiasaan-kebiasaan golongan menak pada saat itu. Kebiasaan yang melekat adalah terkadang agak suka minum-minuman keras saat berpesta. Namun amat jarang sekali tidak sesering kali, hal itu hanya digunakannya agar bisa membaur, menyelami, memahami kebiasaan kultur dalam rangka untuk menasehati masyarakat. Cara seperti yang digunakannya ini telah terbukti efektif untuk merubah

\footnotetext{
${ }^{2}$ http://www.tempo.co/hg/politik/2011/02/28/brk,20110228-316685,id.html

${ }^{3}$ Rosidi. Mr. Sjafruddin Prawiranegara, Lebih Takut pada Allah Subhanahu Wata'ala . 2011.Jakarta:Pustaka Jaya. hlm 31.
} 
kebiasaan rakyat Ngawi. Akhirnya Raden Arsjad justru menjadi bertambah semakin amat dipercaya. Berkat kepercayaannya tadi akhirnya Raden Arsjad ayahnya terpilih menjadi anggota dewan provinsi (provincial raad). Rakyat Madiun menganggap Raden Arsjad Prawiraatmadja ayah Sjafruddin adalah seorang kiyai. Dia sangat taat dalam beribadah, dan juga dikenal sebagai seorang yang bisa, mau dan mampu memahami masyarakat. Raden Arsjad dikenal masyarakat sebagai orang Islam abangan karena sifatnya yang bisa membaur dan memahami masyarakat yang kadang suka peminum. Raden Arsjad wafat ketika sedang mengadakan kampanye untuk pemilihan lagi, tepat saat dia menyampaikan pidato dengan berapi-api yang banyak mengutip ayat-ayat Al Qur'an.4

Ikatan batin Sjafruddin dengan ayah dan keluarganya begitu sangat erat. Keyakinan kepada kebenaran Agama Islam yang kuat telah ditanamkan dalam keluarganya sejak kecil. Hal itulah yang menyebabkan Sjafruddin masuk dan menjadi pengurus Partai Masjumi (Majelis Syuro Muslimin Indonesia). Sjafruddin adalah salah satu di antara lulusan sekolah barat di Indonesia yang senantiasa menyandarkan seluruh aktivitasnya pada kemutlakan iman. Kemutlakan dan kekuatan imanlah yang menjadi dasar atas segala tindakan dan perbuatannya. Rekan-rekannya separtai Masjumi yang berpendidikan baratpun, banyak juga yang berdasarkan pada kemutlakan iman. Mr. Sjafruddin sebenarnya sudah cukup lama agak renggang dari ajaran agamanya. Hal ini dimungkinkan dia agak kurang menyadari peran ajaran tersebut dimasa mudanya.

Semasa kecil Sjafruddin akrab dipanggil dengan "Kuding". Dia sangat gemar membaca kisah petualangan sejenis Robinson Cursoe'. Hal ini menunjukkan bahwa dalam diri Sjafruddin sebenarnya memiliki cita-cita yang tinggi "ingin menjadi orang besar". Sifat ini terlihat tampak dari gaya hidupnya yang suka berpetualang dan terbukti nyata berpengaruh pada karir politiknya. ${ }^{5}$ Istri Sjafruddin bernama T. Halimah Syehabuddin Prawiranegara, seorang wanita kelahiran Aceh dan meninggal dunia pada Agustus $2006 .{ }^{6}$ Hasil pernikahannya dengan T. Halimah Syehabuddin, Mr. Sjafruddin Prawiranegara mempunyai delapan anak dan sekitar lima belas cucu.

Pendidikannya dimulai dari ELS kemudian MULO, AMS (Algeme(e)ne Middelbare School). Dia sebenarnya berkeinginan kuliah di Fakultas Sastra, karena di Indonesia belum ada, maka harus kuliah di Belanda. Akhirnya dia kuliah di jurusan sosial ekonomi RHS (Rechtshogeschool). RHS setara dengan Fakultas Hukum di Jakarta dan tamat tahun 19397. Semasa mahasiswa dia menjadi anggota USI (Unitas Studiosorum Indonesiensis). USI adalah organisasi mahasiswa yang lebih merupakan forum pergaulan pelajar sekolah tinggi tanpa menghiraukan keadaan sosial politik. Ketika disahkannya asas tunggal oleh MPR bulan Maret 1983 sebagai satu-satunya ideologi yang diakui negara, Sjafruddin Prawiranegara menulis surat kepada Presiden Soeharto untuk menjelaskan pendirian kaum muslimin terhadap masalah tersebut". Dia menulis: "Kalau orang-orang Kristen tidak dibenarkan membentuk organisasi atas dasar Kekristenan, baik Protestan ataupun Katholik, dan kaum muslimin tidak boleh mendirikan organisasinya berdasarkan Islam dan begitu pula warga negara Indonesia lainnya yang beragama lain, maka sesungguhnya Indonesia menjadi sebuah negara nasionalisfacis, sehingga keburukan dan kejahatannya tidak berbeda dengan negara-negara komunis".

\section{Jenjang Karir dan Jabatan Mr. Sjafruddin Prawiranegara}

Dia memulai karirnya dari karyawan hingga pimpinan tertinggi. Dia beberapa kali

\footnotetext{
${ }^{4}$ Ibid, hlm 41.

${ }^{5}$ Anonim, 100 TOKOH yang Mengubah Indonesia,( Yogyakarta: Narasi, tt)

${ }^{6}$ Pusat Data \& Analisa Tempo Apa \& Siapa '85/86

${ }^{7}$ Rosidi, Sjafruddin Prawiranegara LEBIH TAKUT KEPADA ALLAH SWT, Biografi, (Jakarta : PUSTAKA JAYA, 2011) hlm 61

${ }^{8}$ Buku Saku Panitia Satu Abad Mr. Sjafruddin Prawira Negara (1911-2011), Sjafruddin Prawiranegara

PENYELAMAT REPUBLIK (Jakarta : Penerbit YAPI, 20011), hlm 71.
} 
sebagai Menteri Keuangan dan telah memperkenalkan uang Republik Indonesia pertama dengan sebutan ORI (Oeang Repoeblik Indonesia). Dia pernah menjadi Menteri Kemakmuran, Perdana Menteri RI, Ketua Pemerintah Darurat RI, Wakil Perdana Menteri RI, Gubernur Bank Sentral/Bank Indonesia yang pertama dengan dua kali masa jabatan, dan Pimpinan Masjumi. Dia juga termasuk pendiri Dewan Dakwah Islamiyah Indonesia, Ketua Korps Mubaligh Indonesia dan lain-lain.

\section{Karya - Karya Mr. Sjafruddin Prawiranegara}

Karya Sjafruddin berupa karangan-karangan hasil pidato, ceramah, ataupun khutbah yang tidak dibukukan secara khusus. Tema ceramahnya tentang filsafat, pandangan hidup, logika, peranan akal yang selalu berlandaskan pada Iman kepada Allah Ta'ala. Alhamdulillah beberapa telah disunting oleh Ajip Rosidi dan dibukukan menjadi 4 jilid diantaranya adalah: Jilid I, yang berisi karangan dan ceramah yang menguraikan soal-soal pandangan hidup dan pendirian dasarnya sebagai seorang muslim (terdiri atas 12 karya), Jilid II berisi karangan atau ceramah yang menguraikan soal-soal social politik, pembangunan bangsa dan negara (terdiri 24 karya), Jilid III berisi karangan atau ceramah yang membahas soal-soal ekonomi dan keuangan, termasuk tentang ekonomi menurut pandangan Islam (terdiri 25 karya), Jilid IV berisi khutbah-khutbah dan surat- surat (terdiri 25 karya).

Mr. Sjafruddin Prawiranegara pada tahun 1951 memulai menjelaskan bahwa Islam mempunyai peranan yang sangat besar dalam sejarah Indonesia. Dia menulis sebuah artikel berjudul "Kedudukan dan Kemenangan Islam Menurut Sejarah". Artikel tersebut dimuat dalam Suara Partai Masjumi (SPM) no.1, Januari tahun 1951. Memang Mr. Sjafruddin Prawiranegara tak henti-hentinya membuat renungan, kritikan, solusi dan klarifikasi. Renungan, pertanyaanpun masih tetap relevan di saat sekarang ini. Renungannya tersebut selama 3 bulan secara berturut-turut dimuat di Suara Partai Masjumi. Pertanyaannya dalam sebuah artikel yang argumentative berjudul "Apakah Modal Asing Berbahaya bagi Bangsa dan Negara Kita?" dimuat dalam SPM no.2,3-4, Februari, Maret-April 1951.

Pada tahun ini Mr. Sjafruddin Prawiranegara sungguh sangat produktif memberikan solusi-solusi cerdas. Karyanya lainnya pada tahun 1951 antara lain berjudul "Akal dan Kepercayaan", dimuat dalam Suara Partai Masjumi no.6, Juni. Pada tulisan ini Mr. Sjafruddin menekankan pentingnya keseimbangan penggunaan otak dan hati. Akal fikiran adalah kerja otak dan keyakinan adalah kerjanya hati. Keduanya harus seimbang dalam penggunaannya.

Mr. Sjafruddin kembali membuat renungan dan peringatan kepada negeri Indonesia yang dicintainya. Sebagai bukti rasa cintanya dia sering memperingatkan seraya memberikan solusinya. Naskahnya sekarang berjudul Indonesia di Persimpangan Jalan, yang diterbitkan oleh Penerbit Al Ma'arif, Bandung tahun 1951. Pada bukunya ini seolah mengingatkan Indonesia untuk sadar bahwa telah keluar dari jalan yang lurus. Jalan yang telah dirumuskan oleh para founding fathers negeri untuk mengantarkan negeri ini kepada kemakmuran, kesejahteraan yang berkeadilan tentunya. Sekarang bisalah dirasakan dan diketahui apakah negeri ini sampai tujuan itu atau belum? Jalan yang ditempuh sudah benar atau belum? Ataukah sekarang masih di persimpangan jalan?. Jikalau masih di persimpangan jalan, hendaklah sadar dan membenahi diri. Sadar dan insyaf adalah solusi tercepat dan teringan yang bisa dilakukan oleh setiap insan warga negeri.

Pada tahun berikutnya 1952, Mr. Sjafruddin langsung memberikan solusi dengan membuat tulisan dalam bentuk pertanyaan. Artikel pertanyaan tersebut berjudul Jalan manakah yang Harus Ditempuh untuk Menyelamatkan Negara Kita?, yang dimuat dalam s.k. Abadi, Bulan Januari. Awal penghujung tahun ini Mr. Sjafruddin memberikan aspirasinya, kira-kira jalan yang manakah harus ditempuh dan dijalani dalam rangka menyelamatkan Negara Indonesia. Semuanya itu dilakukannya karena melihat keadaan Indonesia yang 
telah berada di persimpangan jalan. Mr. Sjafruddin memperkirakan jikalau tetap dipersimpangan jalan sampai kapan akan sampai pada tujuan yang sebenarnya. Makanya dia terus memberikan solusi alternative pemecahan masalah untuk menyelamatkannya.

Tahun 1954, Mr. Sjafruddin Prawiranegara menulis 3 tulisan. Tulisan tersebut diantaranya ditulis bertepatan dengan peringatan Isra' mi'raj. Dia menulis tulisan berjudul Isra' dan Mi'raj Ditinjau dari Sudut Wattenschap. Tulisan tersebut merupakan bahan ceramah di depan Mahasiswa. Wattenschap adalah filsafat. Mr. Sjafruddin Prawiranegara memang sangat senang terhadap filsafat. Dia terkadang melalap habis buku - buku filsafat barat dan Islam. Kemudian Mr. Sjafruddin menulis artikel berjudul Membangun Islam Secara Positip. Tulisan ini juga merupakan bahan untuk sebuah ceramah di Jakarta. Keduanya kemudian diterbitkan bersama dengan judul Hubungan antara Akal dan Iman, dua Ceramah untuk memperingati Isra' dan Mi'raj, CV Abadi, Jakarta.

Buku mengenai kenegaraanpun ditulisnya yang berjudul; Sejarah Sebagai Pedoman untuk Membangun Masa Depan, 1975: Peranan Mu'jizat dalam Perjoangan Kemerdekaan Bangsa Indonesia Prawiranegara, tt, Tindjauan singkat tentang politik dan revolusi kita, 1948; Mau kemana kita dibawa, 1979: Islam sebagai agama perdamaian, persaudaraan \& persatuan serta pelindung Pantjasila 1967; Al-'Aqabah, pendakian jang tinggi : (beberapa pikiran tentang pembangunan), 1971. Buku dibidang ekonomi yang sempat ditulis berjudul Agama dan Ideologi dalam Pembangunan Ekonomi dan Bangsa, 1971; Apa Jang Dimaksud dengan Sistem Ekonomi Islam, 1967; Daftar karya buah tangan Mr. Sjafruddin Prawiranegara sangat bernuansa Islamic Worldview sehingga mampu menginspirasi pembacanya. Sumbangan pemikirannya sangat unik telah memberikan gambaran kedepan, bagai terbit di jaman sekarang dan akan datang.

\section{Intisari Dakwah Mr. Sjafruddin Prawiranegara}

a. Akal dan Keyakinan Sebagai Dasar dalam Berdakwah

Akal yang dibimbing oleh wahyu dapat dipastikan akan membuahkan ilmu yang bermanfaat. Ilmu yang bersumber dari wahyu juga akan membawa pada keyakinan yang mantap. Keyakinan yang mantap dan benar kepada kebenaran yang mutlak. Pemikiran Mr. Sjafruddin tentang keyakinan pada kebenaran mutlak adalah kepercayaan yang paling esensi untuk dapat dipegang. Sjafruddin sangat berkomitmen memegang kebenaran serta tegas\&lantang untuk memperjuangkan. ${ }^{9}$ Ketika dia dengan penuh kesadaran memilih untuk menjadi aktivis Partai Islam bernama Masjumi, maka dia selalu berusaha seluruh sikap, tingkah laku dan pandangannya berdasarkan pada ajaran Islam yang dibawa oleh Rasulullah Shalallahu 'Alaihi Wassalam. Sjafruddin melihat dan berpendapat bahwa inisiatifnya dalam mendirikan PDRI (Pemerintah Darurat Republik Indonesia) sebagai cerminan wujud dari imannya kepada Allah. Dia juga melihat usahanya dalam menegakkan PRRI (Pemerintah Revolusioner Republik Indonesia) guna mengingatkan rejim orde lama yang menyimpang juga sebagai lanjutan imannya.

Islam tidak bisa dicampur dengan faham/isme lainnya. Berdasarkan renungan yang ditulis Mr. Sjafruddin dalam politik dan revolusi kita di Yogyakarta pada Tahun 1948, dia mengakui bahwa Islam dan penganut faham komunisme yang jelas sangat bertentangan. Berkenaan hal tersebut untuk dapat duduk bersama-sama dalam satu forum persatuan perjuangan adalah mustahil. Dia juga melihat bahwa banyak sekali orang mengaku muslim menjadi anggota atau bersimpati dengan PKI, ini adalah salah dan tidak benar. Batas ideologi menjadi tidak jelas, hal ini mungkin disebabkan pemahaman yang tidak jelas tentang ideologi masing-masing.Keyakinan pada kebenaran mutlak adalah kepercayaan yang paling penting. Sjafruddin konsisten memegang teguh pada kebenaran dengan tegas

\footnotetext{
${ }_{9}^{9}$ Wapres Boediono mengatakan bahwa, Mr Sjafruddin Prawiranegara adalah sosok orang yang mempunyai integritas tinggi dan jujur, serta memiliki keberanian. "Benar itu benar, salah itu salah,".sambutan wapres pada peringatan seabad Sjafruddin Prawiranegara di Gedung Bank Indonesia sebagaimana diberitakan di harian kompas tanggal 1 maret 2011.
} 
dan lantang memperjuangkan ${ }^{10}$. Sjafruddin selalu menganalisis segala perkembangan zaman dengan menggunakan akal dengan menyandarkan pendapatnya pada iman. Iman menjadi fondasinya. Menurut Sjafruddin lebih lanjut, Akal yang tidak berdasarkan ketuhanan, sifatnya memecah: selalu menyangkal, menertawakan, memfitnah dan menghancurkan ${ }^{11}$. Akal sudah menanamkan faham persaingan antar kelas yang mengakibatkan permusuhan antara golongan - golongan dalam masyarakat. Akal juga telah menghasilkan alat-alat yang dahsyat mematikan, sampai muncul bom atom untuk menghancurkan sesama manusia.

Akal itu akan menguatkan iman ${ }^{12}$, akal seharusnya disesuaikan dengan iman, dan bukan sebaliknya. "Bahaya akal lebih besar bagi Islam dari lawan yang secara terangterangan memusuhi Islam" kata Sjafruddin. Satu-satunya cara melawannya adalah kembali kepada Al Qur'an dan Assunah. Akal busuk dan oportunisme merajalela sekarang. Manusia berlomba-lomba mencari pengaruh dan kursi jabatan.

\section{b. Dakwah Islam dalam Pergolakan Dunia}

Islam adalah kekuatan rohani yang akan dapat menentukan sejarah. Menurut Sjafruddin, Islam sebagai kekuatan kerohanian (geesrelijke macht) tidak tergantung dan tidak dapat dibatasi oleh ruang dan waktu. Sjafruddin mengemukakan tujuan dakwah Islam tidak untuk menunjukkan kebesaran Islam yang tak perlu diragukan lagi. Islam bisa sebagai spirit rohani perjuangan yang universal. Menurut Sjafruddin tiga hal yang menjadikan Islam sebagai kekuatan rohani menentukan masa datang13:1) karena ajaran- ajaran dan sifat-sifat Islam sebagai firman Allah, 2) berdasarkan Sejarah Islam 3) Islam agama yang sempurna dan penghabisan.

Kemenangan Islam itu bukan karena pedangnya, melainkan karena semangatnya, semangat amar ma'ruf nahi munkar. Islam mempunyai ajaran jihad yang berarti semangat dengan bersungguh-sungguh dalam segala hal. Ajaran inilah yang menginspirasi pemikiran dan membangkitkan ruh umat Islam.

\section{c. Dakwah Islam menurut Kacamata Modern}

Dakwah Islam harus terus berlangsung meskipun jaman ini sudah modern. Seorang da'i hendaknya menyampaikan Islam yang rahmatalil'alamin dengan bekerja keras dan berpikir cerdas, berhati ikhlas, disertai keistiqamahan, kontinuitas. Ketertinggalan dan kemunduran umat Islam dizaman modern, menurut keyakinan Sjafruddin adalah kekurangpercayaan umat ini bahwa Islam adalah agama yang sempurna, sebagai penguasa yang adil dan baik ${ }^{14}$. Menurut Sjafruddin, kalau umat Islam benar-benar percaya bahwa Islam agama Allah, agama yang mutlak benar, seharusnya kaum muslimin memimpin pikiran umat manusia di segala bidang sampai zaman sekarang ini dan seterusnya ${ }^{15}$. Barang siapa yang memimpin pikiran umat manusia, dialah orang akan memegang pimpinan politik. Sebuah anjuran yang luar biasa mulia, agar umat Islam benar-benar meyakini dengan seyakin-yakinnya kebenaran agamanya. Karena hanya dengan keyakinan terhadap Islam yang benar, umat ini akan berpikir bertindak secara Islami. Semangat berpikir di segala bidang akan terkuasai dengan framework Islami. Inilah perlunya umat Islam saling memberikan semangat untuk berpikir dan beramal Islami.

\footnotetext{
${ }^{10}$ Wapres Boediono mengatakan, Mr Sjafrudin Prawiranegara adalah sosok orang yang mempunyai integritas tinggi dan jujur, serta memiliki keberanian. "Benar itu benar, salah itu salah,".sambutan wapres pada seabad sjafruddin Prawiranegara di Gedung Bank Indonesia dalam berita harian kompas tanggal 1 maret 2011.

${ }^{11}$ Prawiranegara, Islam Sebagai Pedoman Hidup, Kumpulan Karangan Terpilih, Jilid I, (Jakarta :Idayu Press, 1986), hlm 62

${ }^{12} \mathrm{Ibid}, \mathrm{hlm} 85$

${ }^{13}$ Ibid, hlm 6

${ }^{14}$ Ibid, hlm 192

${ }^{15}$ Prawiranegara, Islam Sebagai Pedoman Hidup, Kumpulan Karangan Terpilih Jilid I, (Jakarta: Idayu, 1986), hlm 194
} 
Sjafruddin menganjurkan umat Islam, agar supaya dapat memimpin umat manusia, umat Islam harus punya kemampuan kebebasan berpikir. ${ }^{16}$ Pikiran umat Islam harus superior dan unggul. Kebebasan menyatakan pendapat itu menurutnya akan mendidik orang memupuk harga diri dan mengajari kita untuk menghargai pendapat orang lain, walaupun kita tidak setuju dengan pendapatnya. Sebagai seorang da'i hendaknya kebebasan berpikirpun harus sesuai dengan prinsip dan kaidah Islam yang selalu berpedoman pada Al Qur'an dan Sunnah Rasulullah Shalallahu 'Alaihi Wassalam. Kebebasan berpikir dan menyatakan pendapat akan memupuk kreativitas, meninggikan daya cipta pada orang-orang yang turut bertukar pikiran. Para da'i hendaknya berpikir dan bertindak secara Islami.

Ada delapan karakteristik berpikir Islami menurut Dr. Yusuf Qardawi ${ }^{17}$ yaitu; 1) bersifat Rabbani, artinya bahwa pemikiran Islam harus bertitik tolak dari wahyu Ilahi dan sunnah nabawi serta bertujuan untuk meningkatkan pengabdian kepada Allah SWT. 2) Bersifat moralis, artinya pemikiran Islam harus memperhatikan aspek moralitas. Seorang muslim pemikirannya diarahkan kepada masalah-masalah yang berakhlak. 3) Bersifat manusiawi artinya pemikiran Islam menjadikan manusia sebagai objek agar menjadi hamba Allah, ia harus bergerak untuk kepentingan manusia dan merealisasikan kebahagian dan kesejahterannya. 4) Bersifat Universal, artinya pemikiran Islam itu memfokuskan perhatiannya pada kepentingan umat manusia tanpa membedakan suku dan bangsanya maka pemikiran Islam harus bersifat universal yang memperhatikan semua level manusia, golongan dan suku- bangsanya. 5) Bersifat toleran, artinya adanya karakteristik 'toleransi" .nya bersifat universal. 6) Bersifat variatif, artinya pemikiran Islam mempunyai variasi berkisar pada masalah agama dengan berbagai macam cabangnya, bahasa, sastera, filsafat, ilmu alam, matematik, seni dsb. Jadi sifatnya adalah variatif yang mencakup semua aspek kehidupan manusia. 7) Bersifat moderat, artinya pemikiran Islam mencerminkan moderasi antara hak dan kewajiban, ilmu dan iman, materi dan jiwa, individu dan sosial yang menunjukan keseimbangan. 8) Bersifat integral, artinya menyeluruh, terpadu dan tidak dapat dipisahkan. Sebagian pemikiran dalam suatu aspek memiliki keterkaitan yang tak terpisahkan dengan pemikiran dalam aspek lainnya.

\section{d. Masa Depan Dakwah Islam}

Dakwah Islam kedepan seharusnya mampu memenuhi semua kebutuhan manusia. Menurut Sjafruddin perlu membangun Islam secara positip. Makalahnya yang berjudul membangun Islam secara positip ${ }^{18}$ memberikan dasar agar masa depan dakwah Islam lebih partisipatif, integral, dan solutif. Dakwah Islam kedepan akan menghadapi berbagai macam tantangan, hambatan dan gangguan. Iman yang berbuah pada keikhlasan dan akal yang berbuah pada kecerdasan beramal harus dimiliki oleh para da'i. Mr. Sjafruddin berpendapat bahwa yang benar-benar harus dikhawatirkan bukan agama kristen, tetapi agama komunis. ${ }^{19}$ Satu - satunya kekuasaan yang dapat mencegahnya adalah Islam. Umat Islam sekarang masih terlalu lemah sebagai kekuasaan politik. Umat Islam seharusnya bisa memperkuat diri. Hanya Islam yang dapat menahan arus komunis yang atheis di Indonesia. Islam akan mengisi kekosongan agama. Kekuatan Islam yang sesungguhnya terletak pada keyakinan dan keberanian untuk melaksanakan perintah Allah; Amar Ma'ruf Nahi Munkar. Pelaksanaannya akan dapat membentuk persatuan yang kokoh di antara kaum muslimin, Islam dapat melindungi umatnya dari segala ancaman. Islam akan menjadi pemimpin dunia dalam perdamaian dan peradaban yang bermartabat. Berkenaan itu Sjafruddin menghimbau, "umat Islam yang mengaku

\footnotetext{
${ }^{16} \mathrm{Ibid}$, hlm 195.

${ }^{17}$ al Qordlowi, Tsaqofatunaa baina al infitaahi wal inghilaaq, Cet. I (Kairo: Penerbit Daarus Syuruuq, ,2000), hlm. 23-30

${ }^{18}$ Sjafruddin Prawiranegara,op.cit.hlm 84

${ }^{19}$ Ibid, hlm 185
} 
dirinya beriman kepada Tuhan Yang Maha Esa khususnya kaum muslim wajib menggali kembali kekayaan spiritual yang terpendam dalam Al Qur'an dan Alhadist seraya mengamalkannya untuk kepentingan rakyat. Ini jauh lebih penting daripada mencari-cari kursi politik. Umat Islam tidak perlu khawatir akan kekurangan rezeki, Allah beserta orang yang taqwa dan sabar". Allah melalui firmannya telah menjamin dengan kepastian bahwa barangsiapa saja yang bertaqwa pasti akan diberi rezeki dari jalan yang tidak disangka sangka, hanya diperlukan kesabaran dan bersyukur.

Para da'i dalam memperjuangkan kebenaran hendaknya berpedoman pada $\mathrm{Al}$ Qur'anulkarim karena satu - satunya yang datang dari Yang Maha Benar dan akan dijaga keotentikannya sampai akhir zaman. Ilmu hendaknya diamalkan dan berdakwah itu memerlukan kesabaran. Allah telah berfirman dalam Qur'an Surat Al 'Asr ayat 2\&3 yang artinya: "Bahwa manusia itu dalam keadaan merugi kecuali orang yang beriman dan beramal shaleh serta saling menasehati dalam kebenaran dan kesabaran". Mendakwahkan kebenaran yang akan menjadi cahaya dan lentera hidup adalah kewajiban sosial yang mulia. Cahaya adalah simbol kebenaran, bukan cahaya buatan manusia. Menurut Sjafruddin cahaya yang murni, berasal dan bersumber dari segala cahaya yaitu Allah Subhanahu Wata'ala, Tuhan Yang Maha Esa. Apabila ingin bertemu dengan cahaya yang paling murni itu manusia harus bersedia berusaha membersihkan diri dari segala noda yang mengotori jiwanya. Tuhan hanya suka kepada yang jujur, muhsin, dan adil. Jujur ialah yang tidak akan berkata dan berbuat menyimpang dari apa yang diyakini benar. Muhsin ialah yang selalu siap untuk menolong sesama manusia. Adil ialah yang tidak mau mengambil sesuatu bukan haknya, walaupun harganya hanya sepeser. ${ }^{20}$ Sifat jujur, muhsin, dan adil inilah yang benar dan Tuhan yang akan datang membuka rahasia Nya. Umat Islam memerlukan bahan baku untuk mencari kebenaran guna memudahkan hidup manusia.

Mr. Sjafruddin menganjurkan umat Islam agar selalu berusaha membersihkan jiwanya sehingga dapat menerima cahaya kebenaran dari Tuhan. Munculnya hedonisme membuat jiwa manusia kotor. Kekotoran jiwa tercermin dalam kekotoran alam, di darat, sungai, laut dan udara. Semua itu menurut Sjafruddin akibat terjadinya kemorosotan moral manusia. Sjafruddin berpendapat, yang paling bersalah adalah manusia yang menyalahgunakan ilmu pengetahuan alam dan teknik bukan untuk mengabdi kepada Tuhan dan berbakti kepada sesama manusia, tetapi untuk mengeruk kekayaan alam ini demi kepentingan diri dan golongan sendiri. ${ }^{21}$ Kenyataan yang sekarang terjadi sebenarnya telah diingatkan oleh Sjafruddin tahun 1975 dimana terjadi eksploitasi alam dan manusia menurut nafsunya sendiri. Kemajuan ilmu pengetahuan dan teknik untuk menghilangkan kemiskinan material dan spiritual sekaligus. Permasalahan tadi memerlukan penanggulangan, berkenaan hal itu Sjafruddin menganjurkan agar umat Islam membangun masa depan berdasarkan taqwa. ${ }^{22}$ Suatu hal terpenting ialah umat Islam tidak boleh putus asa, putus harapan terhadap kekuasaan-Nya, keadilan-Nya, kemurahan-Nya. Allah mengingatkan janganlah berputus asa akan karunia dan Rahmat Allah, yang berputus asa hanyalah orangorang kafir. Jikalau umat Islam berusaha dan berjuang benar-benar karena Allah, maka tidak akan letih, tidak akan merasakan sakit, tidak takut mati. Tidak ada yang lebih baik daripada mati karena Allah, karena menjalankan kewajibannya terhadapNya. Hidup dan mati ada ditangan Allah, yang harus dikhawatirkan adalah apabila umat Islam melalaikan kewajibannya terhadap keluarga, dan semua kewajiban yang dipikulkan Allah. Jikalau umat Islam benar-benar beriman kepada Allah Subhanahu Wata'ala, maka akan bahagia. Hidup bahagia karena bisa membahagiakan sesamanya.

\section{Peranan Dakwah Sjafruddin Prawiranegara}

\footnotetext{
20 Ibid, hlm 209

21 Ibid, hlm 233

22 Ibid, hlm 244
} 
a. Peranan Dakwah Mr. Sjafruddin Prawiranegara Dalam Bidang Kenegaraan

Dakwah Mr. Sjafruddin Prawiranegara sangat unik dan spesifik, dari awal dia selalu berlandaskan Islamic Worldview yang kuat dalam menganalisis seluruh permasalahan dan tindakannya. Kemutlakan imanlah yang menjadi pangkal tolak dalam menegakkan NKRI. Ketika dia mulai menjabat bahkan sampai jabatan tertinggi sekalipun misi dakwah ilaAllah senantiasa di embannya. Ketika menjadi presiden dan berpidato dalam rangka terbentuknya PDRI dan PRRI misalnya dia selalu bersandar dan menyadari bahwa dia hanyalah tangan kekuasaan Allah Subhanahu Wata'ala, serta dalam rangka mencari karunia dan ridha Allah Yang Maha Kuasa.

Ketika dia menyerahkan mandat PDRI yang tidak pernah sampai ditangannya dia pun berupaya seraya menggapai ridha Allah Subhanahu Wata'ala, bahkan ketika memimpin PRRI untuk mengritik dan mengoreksi Presiden Soekarno yang telah membawa pemerintah pusat menjadi pemerintah dengan demokrasi terpimpin dengan kekuatan komunisme yang sangat berpengaruh, dia berpidato yang isinya "demi menegakkan kebenaran dan keadilan, menjaga kesatuan Republik Indonesia dibawah lindungan dari Allah Yang Maha Kuasa dan Maha Pengasih". Terakhir ketika memberikan instruksi kepada anggota Republik Persatuan Indonesia untuk kembali dan menyerah kepada pangkuan ibu pertiwi, Mr. Sjafruddin menghimbau agar semua dilandasi dan disadari pada pencapaian ridha Allah Subhanahu Wata'ala.

Dakwah Mr. Sjafruddin Prawiranegara bersifat menyeluruh dan totalitas. Kemutlakan imanlah yang menjadi pangkal tolak dalam menegakkan kalimat Allah Subhanahu Wata'ala. Mr. Sjafruddin Prawiranegara menganggap dirinya adalah hanya pemberi peringatan. Baginya memberi peringatan dengan ikhlas dirasa sebagai kewajiban yang sangat mulia. Dia merasa bersalah apabila tidak mengingatkan apabila terjadi melihat kemungkaran/pelanggaran terhadap kebenaran dan keadilan. Menurutnya minimal yang diingatkan itu tahu dan semoga menyadari kesalahannya, kemudian berujung pada taubatannasuha.

Dakwah Mr. Sjafruddin Prawiranegara selalu mampu memberikan arahan dan solusi kepada para da'i, agar berdakwahnya dapat menyadarkan umat pada kesalahannya sehingga berujung pada taubatannasuha dan kembali kepada jalan yang benar dengan kesadarannya. Seorang da'i supaya tidak bertindak seperti jaksa dan hakim yang hanya menyalahkan tanpa memberikan solusi.

\section{b. Peranan Dakwah Mr. Sjafruddin Prawiranegara dalam Bidang Ekonomi}

Peran dakwah Sjafruddin dalam bidang ekonomi sangat banyak. Hal tersebut dapat dilihat dari karier jabatannya dan karyanya. Berdasarkan jenjang karir dan jabatan yang pernah diembannya, dia selalu menjadi pemegang kebijakan penting dalam bidang ekonomi baik semasa penjajahan maupun setelah merdeka. Wapres Boediono mengenang ketika Mr Sjafruddin menjabat Menteri Keuangan dalam Kabinet Hatta pada Maret 1950, melaksanakan pengguntingan uang dari nilai Rp 5 ke atas sehingga nilainya tinggal separuh. Dialah yang memperkenalkan uang Republik Indonesia pertama dengan sebutan ORI ( Oeang Repoeblik Indonesia) sebagai identitas Negara yang berdaulat. Buku dibidang ekonomi yang sempat ditulis berjudul Agama dan Ideologi dalam Pembangunan Ekonomi dan Bangsa, 1971; Apa Jang Dimaksud dengan Sistem Ekonomi Islam, 1967.

\section{c. Peranan Dakwah Mr. Sjafruddin Prawiranegara dalam Bidang Sosial Kemasyarakatan}

Peran dakwah Sjafruddin dalam bidang sosial kemasyarakatan diantaranya ketika Sjafruddin Prawiranegara ditunjuk sebagai ketua umum KMI (Korps Mubaligh Indonesia), seorang publik figur yang memperoleh penghormatan tinggi di masyarakat. Peran Sjafruddin dengan tegas menyarankan agar para da'i dalam berdakwah untuk tidak menimbulkan salah paham, menghimbau dengan sabar, jujur dan penuh tanggung jawab, 
dengan keikhlasan hati menuju penyadaran dan taubat kepada Allah Ta'ala. Peranan dakwah Sjafruddin yang luar biasa adalah perlunya berdakwah secara menyeluruh, integral dan totalitas sesuai posisi dan profesinya masing-masing. Berarti bahwa da'wah Islam "tak mungkin bisa dilepaskan dari soal-soal politik, soal-soal kenegaraan", kata Sjafruddin.

Ditengah maraknya berbagai kajian yang kehilangan arah dan tidak mempunyai framework yang jelas sekarang, peran pemikiran dakwah Sjafruddin di bidang sosial kemasyarakatan menjadi penting sekali. Perlunya umat Islam selalu dan terus berpegang pada pandangan alam Islami dalam berfikir, bertindak dan beramal dimanapun dan kapanpun.

\section{d. Relevansi Dakwah Mr. Sjafruddin Prawiranegara di Masa Sekarang}

Sjafruddin dalam kehidupan kenegaraan adalah seorang yang berpikir jauh ke depan, sehingga banyak pemikirannya yang masih dan tetap relevan di masa sekarang. Wakil Presiden Boediono berpendapat sejumlah pemikiran almarhum Sjafruddin Prawiranegara masih relevan bagi Indonesia kini. Mantan Presiden Pemerintahan Darurat Republik Indonesia sekaligus Gubernur Bank Indonesia pertama itu dinilai menyumbangkan pemikiran mendasar bagi perekonomian bangsa. Berdakwah secara menyeluruh integratif dan totalitas sesuai posisi dan profesinya masing-masing, masih dapat diterapkan dan relevan. Berarti bahwa da'wah Islam "tak mungkin bisa dilepaskan dari soal-soal politik, soal-soal kenegaraan". Demikian pula himbauannya terhadap para da'i agar dalam berdakwah dilakukan dengan sabar, jujur dan penuh tanggung jawab, keikhlasan hati menuju penyadaran dan taubat kepada Allah Ta'ala.

Sjafruddin Prawiranegara merupakan teladan berharga bagi umat Islam khususnya dan Bangsa Indonesia umumnya. Ciri yang paling menonjol dari kepribadian Sjafruddin ialah sikapnya yang teguh, terus terang, jujur, dan demokratis. Sebagai seorang muslim, Sjafruddin merasa dirinya terikat dengan firman Allah Ta'ala dalam Qur'an Surat Ali Imran ayat 104 yang artinya: "Hendaknya diantara kamu ada yang mengajak berbuat benar, serta mencegah berbuat salah". Ajakan itu ditafsirkan Sjafruddin dapat berbentuk lisan, tulisan, atapun perbuatan yang memberi nasehat atau contoh kepada orang lain agar berbuatbaik dan menjauhkan diri dari berbuat jahat ${ }^{23}$. Menurut Wakil Presiden Boediono ${ }^{24}$, banyak prinsip Sjafruddin yang patut diteladani, antara lain integritas yang tinggi, objektivitas, keberanian, dan rasionalitasnya

\section{Kesimpulan}

Dalam Al Quran terdapat banyak ayat yang berkaitan dengan prinsip-prinsip pemberdayaan masyarakat. Al Quran juga menawarkan solusi nyata (practical solution) yang bisa diaplikasikan dalam membantu keberhasilan program pemberdayaan masyarakat. Ada tiga prinsip pemberdayaan masyarakat menurut perspektif Al Quran. Yang pertama adalah prinsip ukhuwwah. Islam mendorong umatnya untuk saling membantu satu sama lain, dalam kerangka ukhuwwah Islamiyah dan ukhuwah insaniyyah. Yang kedua adalah prinsip ta'awun. Prinsip ini menegaskan bahwa program pemberdayaan adalah tanggung jawab bersama, dan harus berlandaskan sinergi yang efektif antara pemangku kebijakan, praktisi dan penggiat sosial, dan masyarakat luas. Yang ketiga adalah prinsip persamaan derajat, di mana Islam menekankan kesamaan derajat antara umat manusia.

Menurut perspektif Al Quran ada beberapa langkah yang dapat dilakukan dalam membantu keberhasilan program pemberdayaan masyarakat. Yang pertama yaitu pengembangan diri yang berkesinambungan. Masyarakat yang menjadi klien program pemberdayaan dituntut agar mampu mengembangkan diri dan bekerja untuk

${ }^{23}$ Rosidi,op.cit.hlm 407

${ }^{24}$ Sebagaimana disampaikan pada peringatan seabad mr. Sjafruddin Prawiranegara 
meningkatkan taraf hidup dan nasib mereka. Yang kedua yaitu melakukan pendidikan dan pembinaan kepada masyarakat, di mana skill dan ketrampilan merupakan salah satu faktor yang menjadi penggerak ekonomi masyarakat. Yang ketiga adalah melaksanakan dan mendorong zakat dan infak, dua program yang sangat ampuh dalam mengangkat masyarakat dari garis kemiskinan. Yang juga dituntut adalah pengelolaan zakat yang lebih efisien dan professional, demi mewujudkan pemberdayaan yang lebih efektif. Yang terakhir adalah menjauhi perilaku ekonomi yang dilarang oleh agama Islam seperti penimbunan bahan pokok (hoarding) dan monopoli (ihtikar), karena perilaku tersebut merugikan masyarakat dan tidak sejalan dengan ajaran Islam yang mengusung semangat keadilan sosial.

Pemberdayaan masyarakat adalah salah satu instrumen penting dalam mengentaskan kemiskinan. Sebagai agama rahmatan lil 'alamin, Islam mendorong umatnya untuk mewujudkan keadilan sosial dan kesejahteraan bagi semua. Dalam perspektif Islam, program pemberdayaan masyarakat sangat sejalan dengan semangat dan ruh Islam yang mengkader pemeluk-pemeluknya untuk menjadi agen penyebar rahmat Allah SWT.

\section{Daftar Pustaka}

Abdulrahman, Jalaluddin, tt. Jami'ushaghir, Juz. II Dar Ihya Al-kutub, Al Arabiyah.

Adnan. 2004. Islam Sosialis Pemikiran Sistem Ekonomi Sosialis Religius Sjafruddin Prawiranegara. Jogjakarta: Pustaka RaSAIL Menara Kudus.

al Qordlowi, Yusuf. 2000. Tsaqofatunaa baina al infitaahi wal inghilaaq, Cet. I Kairo: Penerbit Daarus Syuruuq.

Badriah, Sederhana Hingga Akhir Hayat. Tempo, edisi Selasa, 01 Agustus 2006

Brosur Pedoman untuk menjalankan Dakwah Islamiyah Indonesia, Yayasan Korps Muballigh Indonesia, Jakarta.1985

Kahin, George McT. 1999. IN MEMORIAM:SJAFRUDDIN PRAWIRANEGARA (1911-1989)

Munadjat, Imam. Nilai Moral Sjafruddin Sjafruddin Prawiranegara. Harian Suara Merdeka tanggal 27 April 2011

Munadjat, Imam. Menyemai Kejujuran Mr. Sjaf. Harian Suara Merdeka tanggal 26 April 2011 Panitia Satu Abad Mr. Sjafruddin Prawiranegara (1911-2011). 2011. Sjafruddin Prawiranegara PENYELAMAT REPUBLIK. Jakarta: Penerbit Yayasan Asrama dan Pendidikan Islam.

Prawiranegara, Sjafrudin. 1986. Islam sebagai Pedoman Hidup. Disunting Ajip Rosjidi, Kumpulan karangan terpilih. Jakarta: Indayu.

Rosidi, Ajip. 2011. Sjafruddin Prawiranegara lebih takut kepada Allah SWT Biografi. cet. keII, Jakarta : Pustaka Jaya.

Satu Abad Menkeu Sjafruddin Prawiaranegara, Harian Kompas tanggal 1 Maret

Shiraji, A. Mujib El. Naluri Kenegarawanan Mr. Sjaf, Harian Suara Merdeka tanggal 10 Mei 2011

Sriyanto, M.P.I, 2017 Sang Penyelamat Republik Pro U Media Yogyakarta 